\title{
Aviation English Training for Aviation Personnel in Ukraine
}

\author{
L. Nemlii \\ National Aviation University, Kyiv, Ukraine \\ Corresponding author. E-mail: nemliy_mila@ukr.net
}

Paper received 08.09.20; Accepted for publication 24.09.20.

\begin{abstract}
https://doi.org/10.31174/SEND-Ph2020-235VIII70-08
\end{abstract}
\begin{abstract}
The article aims at investigating how the implementation of the International Civil Aviation Organization's (ICAO) language proficiency requirements is provided at high school and post-graduation institutions. As pilots and air traffic controllers have to communicate in English doing their professional activities, they are trained English language as Aviation English while getting the education and after graduation. Pilots and air traffic controllers are demanded to have level 4 Operational to provide radio communication and the air traffic operation safety. That is why language proficiency skills are trained and tested regularly to satisfy the ICAO recommendations.
\end{abstract}

Keywords: Aviation English, pilot, Air Traffic Control Operator, ICAO language proficiency, post-graduate education, ICAO language requirements, Standard Phraseology.

Introduction. Aviation English is an international language for civil aviation. All air traffic controllers (ATC) and pilots who operate international flights are required to have a certificate in Aviation English level 4 in accordance with International Civil Aviation Organization (ICAO) requirements. This level is known as an Operational level. Due to ICAO Doc. 9835 AN/453 pilots and ATCs possessing Aviation English level 4 are able to communicate with each other, understand each other while operating the air traffic thus they provide safety of flights [1]. In accordance with the ICAO guidelines for Aviation English training programs, the emphasis is put on the communication approach to language learning with the objective to improve speaking, listening and interactive skills [2].

To maintain the language at necessary level mentioned above specialists have to obtain their English language communication skills at high school first and then they need to practice them regularly after the graduation while doing a job. That is why air companies all over the world organize language retraining classes for their personnel every year as a refresh course and once per four years pilots and ATCs are prepared for ICAO Aviation English test. This test is provided by independent companies which have a license to test and award a certificate which shows the demonstrated by a speaker Aviation English level 3, 4 or 5 during a test. The procedure of a test is organized due to ICAO recommendations either. It consists of several tasks which give a candidate possibility to demonstrate his communication and listening comprehension skills and competence at necessary level. The aim of the ICAO Language Proficiency Test is to verify the applicant's language skills in the following areas: general and aviation vocabulary; use of standard phraseology; understanding aviation recoding and ability to retell in a few words; ability to communicate correctly in an ATC'S pilot's dialogue; explain the reasons, consequences and pilot's or ATC's action in any emergency situation [3].

The aim of the research is to explore how effectively the Aviation English teaching is organized and if the students are able to ensure their language level proficiency during a test.

Materials and methods. Doing a research, we used a range of appropriate methods such as literature review, ICAO document analysis, interviewing of Ukrainian teachers. Comparative analysis of different aspects in teaching Aviation English has been conducted on structural, organizational and content levels. To our opinion Aviation English training for aviation personnel in Ukraine would be further provided at high methodological level in accordance with ICAO language proficiency requirements.

For our analysis we selected well-known Ukrainian aviation universities and post-graduate institutions: National Aviation University, Ivan Kozhedub National Air Force University, Language Training Center Aerolingua, Foreign Language Center "Interbridge" and Training and Certification Center (TCC) of Ukrainian State Air Traffic Services Enterprise (UkSATSE) in Ukraine.

To be familiar with different approaches used in the Aviation English training process, preferences of choosing and structuring the content of the educational program and pedagogical techniques of the classes we studied legislative and regulatory documents. For airmen Aviation English training such documents are ICAO regulations stipulating English proficiency and educational institutions following ICAO requirements completed their educational programs.

Results and Discussion. In Ukraine ICAO test was constructed to give possibility the Rator to measure the candidate's level of English. During the text the participant should demonstrate the following language abilities: ability to use general English in aviation circumstances precisely (pronunciation, vocabulary, grammar) though some mistakes are not significant if they are made in complex language; ability to communicate fluently while interacting with an interlocutor (e.g., respond immediately); ability to produce language expense, using appropriate connectors and fillers; ability to clarify and paraphrase if it necessary; ability to communicate successfully in unpredicted situations of unprepared topic (turn of events), linguistic or situational complication [4].

So, to pass a test successfully aviators have to be ready for test and that is why practical classes are organized regularly.

As we are interested in Aviation English training organized in Ukraine, we can mention that there are some companies which provide high level training and do this effectively in accordance with innovative methodological standards. Innovative and interactive methods are used to train pilots' and ATCs' English communication skills and competence. Educational process must be specially created in which necessary competencies are formed as components 
of ATC's professional competence by means of advanced training methods and techniques [5]

As at high school so at post-education institutions during classes students practice communicative situation based on topics dealing with routine and non-routine or emergency situations like Bird Strike, Engine Failure, Severe Weather and others.

In routine situations air specialists like pilots or ATCs use standard phraseology. Aviation standard phraseology is a list of radiotelephony words or phrases that may be encountered during a controlled flight. These words and phrases are clear and accurate in meaning which is vital for safe operation of aircraft. Standard phraseology has been carefully developed to provide maximum clarity in radiocommunication during routine situations. The usage of these phrases helps ATCs to transmit much information within short period of time and to control lots of air traffic simultaneously. Standard phraseology reduces the risk that the instruction or any other message will be misunderstood plus read back procedure will quickly give possibility to identify any mistake. In too big airports within heavy traffic standard phraseology provides non-stop air regulation.

However, while standard phraseology is used in routine situations, in emergency situations it would not be enough and plain English is in need. As pilots have to explain the emergency, sometimes its reasons, they can predict the consequences and have to explain the situation to ATC, they have to inform about their intention concerning the flight if they need to land immediately or if they continue the flight, they will use Aviation English.

Aviation English is considered to be an international language of civil aviation used by pilots and ATCs to operate the air traffic using aviation terminology and general English. In the same case ATC will assist pilots following the standard procedure which takes into account all possible emergency situations and pilots and ATCs actions in emergency are predicted and regulated ahead. Thereby Aviation English vocabulary is predictable either and has to be learnt and practiced behead during arranged practical classes. Class practical experience will ensure safety of air regulation provided by pilots and ATCs while doing their professional activities.

Why does Aviation English emergency situations' vocabulary need to be practiced? First of all, standard phraseology is enough to regulate the flights in routine situations, minimum words and phrases help to save time and express the instructions accurate. However, they are not enough in emergency situations as a specific situation needs special explanation. Secondary, most of the pilots and ATCs are not native English speaker and they can be lack of the vocabulary. Even if they are native speaker and are good specialist in air traffic service, they can use not clear language like idioms, phrasal verbs, words with different meanings which could make the situation worth as their interlocutor can find it difficult to understand. In aviation history there were some facts when pilots and ATCs understand each other. For example, one said: "hold on" meaning "wait" while the other understood it like "keep on" meaning "continue". To avoid misunderstanding pilots and ATCs study Aviation English at different levels of their career, first at the university then at post-graduation institutions. In Ukraine there are several high schools such as National Aviation University, Kirovograd Flight Academy, Ivan
Kozhedub National Air Force University where pilots and ATCs are trained. The Extended Curriculum of the university in the Speciality Aviation Transport includes Aviation English practical classes.

During practical classes students are trained to deal with all possible routine and non-routine situations (emergency). The Aviation English classes are organized via interactive teaching methods aim to provide future pilots and ATCs with all necessary skills which need to be later estimated due to ICAO scale like pronunciation, sentence structure, vocabulary, fluency, comprehension, interaction. Studying the Educational Curriculum of 272 Aviation Transport we observe that students have 240 hours totally, 132 practical classes and 108 hours for self-studying. During the Aviation English course students are practicing topics concerning emergency situations, practice vocabulary and study basic grammar structures.

University Aviation English teaching methodological background

Aviation English at NAU is taught by Aviation English teachers who were specially trained for conducting such classes at a private company Aerolingua which has a license to provide such training for teachers of English [6].

The classes of Aviation English are organized in accordance with educational program and course training program. Among the class topics are routine situations like "Weather", "Health", Taking off procedure", "Landing" and emergency situations like "Severe weather", "Unlawful Interference", "Engine Failure", "Belly Landing", "Ditching" and others. All situations are studied via interactive tasks like role-play, debates, round table, microphone and others.

An example of the task for monologue speech development is:

Task1. Read the situation and say what you would do in it.

You are an approach controller in a busy airport. An incoming English-speaking pilot has requested a priority landing for a heavy aircraft. He has repeated the request but you still cannot understand the reason [7].

One important fact is the necessity of high level of listening comprehension skills development as our participants will be always in two-way communication. They have to get used to usage of headset because their future job requires not face-to-face communication but radio connection. Pilots and ATCs have to understand each other to be correct in their own instructions and decisions made based on the report they heard. To develop listening comprehension skills students are given tasks to listen to the exchange and make a conclusion and give a suggestion. One practical exercise is to fill the gaps adding the information you hear, true or false, and answer the question or add a reply.

For example: Task 1. Imagine you are having a radio exchange and need to reply. Fill the gaps giving possible instructions or the variant of your reply.

Pilot: - Pan-pan, pan-pan, pan-pan, Bellevua Aproach, GAV 737, request emergency medical support on landing.

ATC: -

Pilot: -What is the distance?

ATC:

Task 2.

ATC: -Sorry, you are totally unreadable. 
Pilot: [7].

This type of practical exercise can be done individually or in class where several students will suggest their answers. There are keys to control and check if it is necessary and comment the students' reply.

To combine development of listening comprehension skill and monologue speech, after listening to the radio exchange retelling is suggested but not only a student should make a conclusion if the ATC's or pilot's actions were correct, and add his imagine concerning the end of the situation.

Watching a video is a good way to develop listening comprehension skills too. Different tasks for video help to check students' understanding and to develop other language skills like reading, communication and writing. Students are interesting in watching and discussion videos and their motivation bring a great effect to their skills that is why every module includes video-lesson.

Post-graduation training

As it was already mentioned above every four years pilots and ATCs pass a test for the level 4 and to enhance pilots' and ATCs' knowledge in Aviation English there are lots of post-graduation institutions like schools or courses in Aviation English. All training modules contain the information and tasks to reflect the pilots' and ATCs' work environment. The aim of the classes is to provide the participant with high level of English-communicative skills that is why to make classes effective communicative skills are developed through a variety of realistic scenarios, which take place in regular operations, routine and nonroutine situations, Standard ICAO phraseology is trained either where and when it is required as radio communication between a pilot and ATC cannot be done without it. It is worth mentioning that course language training is done due to ICAO recommendations to language proficiency and aimed to supply the participants with high language skills which will give them ability to pass the ICAO test successfully and prove safety of flights.

In Ukraine after graduation pilots and ATCs can support their Aviation English level at several post-graduation institutions like at state and private companies, Ukrainian International Airlines provide their pilots training themselves. Private pilots usually choose what company to be trained at themselves.

An author's course of Aviation English for pilots and ATCs is suggested by a training center Aerolingua. The program is aimed at English language skills formation which would ensure the candidate effective communication during radiotelephony in non-standard and/or emergency situations when phraseology is not enough to achieve full understanding during the flight performance. This course includes exercises for learning special vocabulary, grammatical structures as well as tasks targeting skills to speak and hear correctly. The course is based on thematic units in accordance with the stages of flight and the list of non-standard / emergency situations. During the training, special focus is on various zones of air traffic control $[5,6]$

Foreign Language Center "Interbridge" supply Aviation English training for pilots and ATCs too. The teaching staff arrange Aviation English training within the framework of ICAO standards: after training, participants can successfully pass the test for obtaining or improving the level 4 or
5 and getting the permission for international flights. The company suggests an interactive training format. Students can practice in classrooms or online. During classes students study aviation vocabulary and standard phraseology of radio exchange, they practice it in the circumstances of artificially created non-standard situations. All lessons are based on the general English level of definite student. Due to student's level of English an individual lesson planning is provided by teachers.

During Aviation English lessons ATCs and pilots are practicing their communication skills within professional situations. Standard situations that are trained at the lessons are routine and non-routine situations which are among their professional responsibilities; fire on board; emergency landing; change of route; important messages for passengers; assistance to passengers; elimination of conflicts in the cabin; seizure of the aircraft by terrorists and others. Learning terminology, practicing professional topics, overcoming the language barrier are among goals of studying on courses. During course session, students discuss significant possible moments of their work, as well as ways to deal with them. This subsequently helps successfully pass the test [8].

There is also a state TCC of UkSATSE in Ukraine. The success of TCC has been based on the quality of the training programs and the professionalism of their high-level teaching staff who are well-experienced in the methods of aviation personnel training [9]. TCC arranges aviation personal professional training and language training as well. In the area of language training the teaching staff is aware of effective aviation personnel language training implementation to satisfy the ICAO and EUROCONTROL language proficiency requirements and standards. As Aviation English teaching is not an easy task, there is no guarantee that everyone will succeed in practicing language skills at the same rate. Therefore, all the language training programs designed by TCCs experts comply the basic teaching principles. They are: English teaching based on communicative and English-only approach; Science-based support, as an effective aid for controlling if programs are appropriate; Quality control, done for testing at any phase of language training to check the individual results of English language skills development in order to improve the program.

TCC provide two different programs for language training for participants who eager to demonstrate their language proficiency at level 4 and level 5. Both programs for Aviation English training includes job related topics.

They are created to renew and maintain the level of communication skills in English, which are used for radiotelephone communication; to activate language competence (grammatical, lexical, phonetic); speech competence in reading, listening and speaking; skills to percept oral speech in the aviation context; the language strategy which is necessary in case of unpredictable conditions in flight and others. All of the mentioned language skills are trained because of the requirements of Doc ICAO 9835 AN/453 [1].

Conclusion. The education institution in Ukraine which provide Aviation English training for aviation personnel follow the ICAO recommendations in language training arrangement in order to supply their students with necessary language skills and competence to be ready to pass test 
successfully. As ATCs' and pilots’ English level 4 gives them a way to operation international flights, trainees use their opportunities to enlarge their aviation vocabulary, prove their communication skills, study phraseology, take parts in all suggested discussions while training Aviation English to upgrade their professionalism which will provide safety of flights while doing a job through radio communication.

\section{REFERENCES}

1. ICAO 2010 Manual on the Implementation of ICAO Language Proficiency Requirements/ ICAO Doc 9835 AN/453: ICAO Second Edition

2. Bystrova B, Nemlii L, Pazyura N and Vasyukovych O 2019 Problem-based ESP methods for teaching future air traffic controllers to conduct radio exchange in non-routine situations Advanced Education 12 74-79 DOI:10.20535/24108286.155041

3. https://blueskyaviation.cz/en/zkouska-letecka-angli

4. Petraschuk O The Aviation English Test Development Retrieved from: http://er.nau.edu.ua/handle/NAU/11912

5. Petraschuk O Vasiukovych O 2015 Rationale for linguistic profile of Aviation English language training course Proceedings of National Aviation University 58(1) 84-89 Retrieved from: https:/doi.org/10.18372/2306-1472.63.8878

6 www.aerolingua.com

7. English for Aviation for Pilots and Air Traffic Controllers. Sue Ellis and Terence Gerighty - Ox. University Press - 2015.96p.

8. https://interbridge.com.ua/avia-english/kursy-aviacionnogoangliyskogo-yazyka.php

9. http://tcc.uksatse.aero/en/

10. http://tcc.uksatse.aero/wp-content/uploads/2019/cata$\log$ UA.pdf 